\title{
АДАПТАЦІЙНИЙ ПОТЕНЦІАЛ ОСОБИСТОСТІ ЯК ВНУТРІШНІЙ ЧИННИК УСПІШНОї АДАПТАЦІї МОЛОДШИХ ШКОЛЯРІВ І3 ПОРУШЕННЯМИ ЗОРУ
}

Вадим КоБИЛьчЕНко, Інститут спеціальної педагогіки і психології імені Миколи Ярмаченка НАПН України, м. Київ, Україна; vadimvk@ukr.net

Визначено, що соціальна адаптація трактується як процес активного пристосування індивіда до умов соціального середовища. Не зважаючи на безперервність адаптації, це явище пов'язують, насамперед, 3 періодами кардинальної зміни життєдіяльності індивіда і його соціального оточення. У дитинстві таким періодом передусім $€$ початок шкільного навчання. Визначено, що під адаптивністю зазвичай розуміють наявність певних здібностей, що дають змогу особистості найбільш швидко й адекватно вирішувати проблемні ситуації та нормалізувати свою взаємодію з середовищем. Теоретично обґрунтовано структуру адаптаційного потенціалу особистості, розроблено його модель. Розкрито сутність та функції адаптаційного потенціалу особистості як внутрішнього чинника успішної соціальної адаптації молодших школярів із порушеннями зору.

Ключові слова: соціальна адаптація, адаптивність, шкільна дезадаптація, адаптаційний потенціал особистості, молодші школярі з порушеннями зору.

Вадим КОБЫЛЬЧЕНКО, Институт специальной педагогики и психологии имени Николая Ярмаченко НАПН Украины, г. Киев, Украина

Адаптационный потенциал личности как внутренний фактор успешной адаптации младших школьников с нарушениями зрения

Определено, что социальная адаптация трактуется как процесс активного приспособления индивида к условиям социальной среды. Не считаясь с непрерывностью адаптации, это явление связывают, прежде всего, с периодами кардинального изменения жизнедеятельности индивида и его социального окружения. В детстве таким периодом, прежде всего, является начало школьного обучения. Определено, что под адаптивностью по обыкновению понимают наличие определенных способностей, которые позволяют личности наиболее быстро и адекватно решать проблемные ситуации и нормализовать свое взаимодействие со средой. Теоретически обоснована структура адаптационного потенциала личности, разработана его модель. Раскрыта сущность и функции адаптационного потенциала личности как внутреннего фрактора успешной социальной адаптации младших школьников с нарушениями зрения.

Ключевые слова: социальная адаптация, адаптивность, школьная дезадаптация, адаптационный потенциал личности, младшие школьники с нарушениями зрения.

(C) Кобильченко В., 2019 
Vadym KOBYLCHENKO, Mykola Yarmachenko Institute of Special Education and Psychology of the NAES of Ukraine (Ukraine), Kyiv, Ukraine

Adaptation potential of the personality as the internal factor of successful adaptation of younger school students with sight violations

It was determined that social adaptation is treated as a process of active individual adaptation to the social environment conditions. Ignoring the continuity of adaptation, a phenomenon associated primarily with periods of fundamental change in the individual's life and his social environment. As a child in such a period, first of all, it is the beginning of schooling. It was determined that under adaptability as usual understand the presence of certain abilities that allow the individual the most rapidly and adequately address the problem of the situation and normalize its interaction with the environment. Theoretically substantiated structure of the adaptation potential of the person, his model has been developed. The essence and function of the adaptive potential of the person as an internal factor of successful social adaptation of younger school students with visual impairments. Adaptive potential systemic taken regarded as individual property that determines the borders of adaptive capacity and character of individual adaptation in response to the impact of various factors and environmental conditions. Features of the adaptation potential mediating effect of environmental factors determine the direction, content, intensity adaptive response of the individual. The analysis of adaptation potential, the hierarchy of its elements, quality originality of its internal and external relations, perhaps, is the key to a correct and reliable prediction of the adaptation process, improving the efficiency of its programs of psychopedagogical support, providing individualized psychological care.

Keywords: social adaptation, adaptability, school disadaptation, adaptation potential of the personality, younger school students with visual impairments.

Постановка проблеми. У сучасній психології соціальна адаптація трактується як процес активного пристосування індивіда до умов соціального середовища. Соціальну адаптацію зазвичай пов'язують із періодами кардинальної зміни діяльності індивіда та його соціального оточення. Важливим їі аспектом вважають прийняття індивідом соціальної ролі. Саме цим зумовлено віднесення соціальної адаптації до одного з соціально-психологічних механізмів соціалізації особистості. Ефективність соціальної адаптації в значною мірою залежить від того, наскільки адекватно дитина сприймає себе та свої соціальні зв'язки.

Оскільки умови соціального середовища ніколи не залишаються незмінними, то процес адаптації безперервний. Але, не зважаючи на безперервність адаптації, це явище пов'язують, насамперед, з періодами кардинальної зміни життедіяльності індивіда і його соціального оточення. У дитинстві таким періодом передусім є початок шкільного навчання. Адже від того як почнеться шкільна біографія дитини залежить адаптація на наступних етапах і увесь процес соціалізації й розвитку особистості учня.

Формулювання мети статті. Набуває актуальності теоретичне обгрунтування та розроблення моделі адаптаційного потенціалу особистості. У цьому

«ОСОБЛИВА ДИТИНА: навчання і виховання», № 3, 2019 
контексті, метою нашої статті є обгрунтування структури та функцій адаптаційного потенціалу. Відповідно, мета нашого дослідження відображена в наступних завданнях: теоретично обгрунтувати структуру адаптаційного потенціалу; визначити функції, які виконують структурні компоненти в процесі соціальної адаптації молодшого учня з порушеним зором.

Виклад основного матеріалу дослідження. Розглядаючи адаптацію дитини до школи, дослідники виділяють рівні, механізми й показники адаптації. Так, О. Венгер [4] розглядає адаптованість як систему якостей особистості, умінь і навичок, що забезпечують успішність наступної життєдіяльності й виділяє три рівні адаптованості першокласників:

1. Високий рівень адаптації. Першокласник позитивно ставиться до школи, пропоновані вимоги сприймає адекватно, навчальний матеріал сприймає легко, глибоко й повно опановує програмним матеріалом, вирішує ускладнені завдання. Старанний, уважно слухає вказівки й пояснення вчителя, виконує доручення без зовнішнього контролю, виявляє велику цікавість до самостійної роботи. Завжди готується до всіх уроків, суспільні доручення виконує охоче й сумлінно. Займає в класі сприятливе статусне положення.

2. Середній рівень адаптащї. Першокласник позитивно ставиться до школи, їі відвідування не викликає негативних переживань. Розуміє навчальний матеріал, якщо вчитель викладає його докладно й наочно, засвоює основний зміст навчальних програм, самостійно вирішує типові навчальні завдання. Суспільні доручення виконує сумлінно, дружить із багатьма однокласниками.

3. Низъкий рівень адаптації. Першокласник негативно або індиферентно ставиться до школи, нерідкі скарги на нездоров'я, домінує пригнічений настрій. Спостерігаються порушення дисципліни, матеріал, що пояснює вчитель, засвоюється фрагментарно, самостійна робота з навчальним матеріалом утруднена, до уроків готується нерегулярно, необхідний постійний контроль, систематичне нагадування й спонукання з боку дорослого. Зберігає працездатність й увагу під час подовжених паузах для відпочинку, для розуміння нового й виконання завдань за зразком потрібна значна допомога вчителів і батьків. Суспільні доручення виконує під контролем, без особливого бажання, близьких друзів не має, знає по іменах і прізвищах тільки частину однокласників.

Із цих описів видно, що основні характеристики адаптованості зводяться до засвоєння шкільного матеріалу й виконання шкільних обов'язків.

Інші автори [3] для аналізу процесу адаптації молодших школярів використовують чотири критерії:

- ефективність навчальної діяльності (навчальна активність і засвоєння знань);

- засвоєння шкільних норм поводження на уроці й перерві;

- успішність соціальних контактів (відносини з дітьми й учителями);

- емоційне благополуччя. 


\section{BEKSOP TPAHROCOPMANUIII}

Важливою особливістю такого підходу є орієнтація на наступний принцип: відсутність показників адаптації одночасно виступає як наявність показників дезадаптації.

Т. Дорожевець [6] розширює діапазон критеріїв і показників адаптації дитини до школи, пропонуючи іï трикомпонентну модель. Шкільна адаптація, на думку автора, здійснюється в трьох сферах:

1) академічній - характеризує ступінь відповідності поводження дитини нормам шкільного життя, прийняття вимог учителя й ритму навчальної діяльності, оволодіння правилами поведінки в класі, ставлення до школи, достатню пізнавальну активність на уроках тощо.

2) соціальній - відображає успішність входження дитини в нову соціальну групу у вигляді прийняття дитини однокласниками, достатньої кількості комунікативних зв’язків, уміння вирішувати міжособистісні проблеми тощо.

3) особистісній - характеризує рівень прийняття дитиною самої себе як представника нової соціальної спільноти («Я - школяр») і виражається у вигляді відповідної самооцінки й рівня домагань у шкільній сфері, прагнення до самозміни й т. ін.

В останні роки для опису різноманітних проблем і труднощів, що виникають у дітей у зв’язку з навчанням в школі, почали використовувати поняття «шкільна дезадаптація».

Шкільна дезадаптація - це утворення неадекватних психологічних механізмів пристосування дитини до школи у формі порушень навчання й поведінки, конфліктних стосунків з найближчим соціальним оточенням, психогенних захворювань і реакцій, підвищеного рівня тривожності, порушень в особистісному розвитку тощо. 3 цим поняттям пов'язують відхилення в навчальній діяльності - труднощі в навчанні, конфлікти з однокласниками тощо.

3 нашої думки, шкільна дезадаптація виявляє себе на декількох рівнях:

1) пізнавальний рівень. Дитина хронічно не справляється зі шкільною програмою. При цьому вона може безуспішно намагатися перебороти труднощі або відмовляється вчитися в принципі;

2) соціальний рівень. Шкільна дезадаптація проявляється в імпульсивній і неконтрольованій поведінці, агресивності, неприйнятті шкільних правил, неадекватності вимог до однокласників і вчителів. Причому діти залежно від характеру й фізіологічних особливостей можуть поводити себе по-різному. Одні будуть проявляти імпульсивність і агресивність, інші - тривожність і неадекватні реакції;

3) емоційний рівень. Дитина негативно ставиться до школи, не хоче туди ходити, не може налагодити стосунки з однокласниками й учителями. Погано ставиться до перспективи навчання. При цьому важливо розрізняти окремі складності, коли дитина зіштовхується із проблемами й скаржиться на це, i ситуацію, коли вона загалом украй негативно ставиться до школи. У першому випадку звичайно діти прагнуть перебороти проблеми, у другому або опускають руки, або проблема виливається в порушення поведінки.

«ОСОБЛИВА ДИТИНА: навчання і виховання», № 3, 2019 
Як ми неодноразово відзначали в своїх працях [2; 7], особистісний розвиток дітей з порушеннями зору відбувається в умовах поліфакторної депривації, при цьому простежується чітка закономірність: різні види депривації комплексно впливають на процес адаптації дитини до школи, зумовлюючи дезадаптацію на різних їі рівнях (рис. 1). Розглянемо їх далі більш детально.

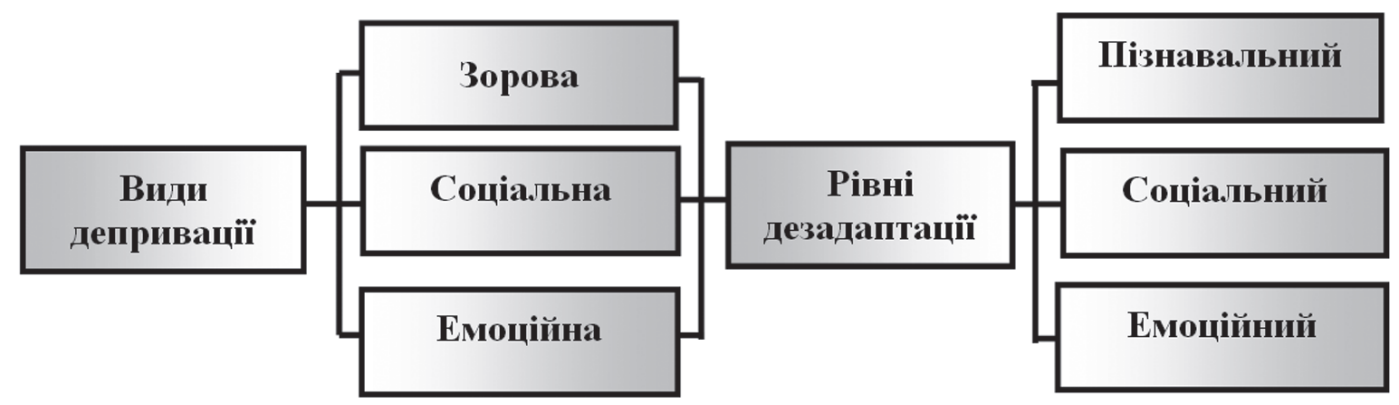

Рис. 1. Роль поліфакторної депривації у виникненні шкільної дезадаптації

Навчальна діяльність вимагає певного запасу знань про навколишній світ, сформованості елементарних понять. Дитина повинна володіти розумовими операціями, уміти узагальнювати й диференціювати предмети і явища навколишнього світу, уміти планувати свою діяльність та здійснювати самоконтроль.

На початку шкільного навчання егоцентричне мислення дошкільника змінюється здатністю до конкретних розумових операцій. Йому стають доступними такі з них, як децентрація, зворотність, уміння подумки простежувати зміни об'єкта. Проте мислення молодшого школяра обмежується тим, що стосується переважно реальних об'єктів, конкретних життєвих ситуацій, що тісно пов'язані з його індивідуальним досвідом. Крім того, існує пряма залежність - чим більше інформаційних каналів сприймання залучено в процес запам'ятовування, тим кращим є результат.

Важливими також ж є позитивне ставлення до навчання, спроможність до саморегуляції поведінки і прояв вольових зусиль для виконання поставлених завдань. Не менше важливі й навички спілкування [7], розвинена дрібна моторика рук і зорово-рухова координація.

Дитина з порушеним зором часто не здатна адекватно сприймати й оперативно опрацьовувати надзвичайно насичений потік нової інформації, що часто проявляється в імпульсивному реагуванні, у поверховому сприйманні інформації та їі аналізі.

Це, на думку Л. Солнцевої [9], призводить до формування у дитини психічних комплексів, що заважають створенню системи компенсації зорової недостатності, в основі якої значне місце займають розвинені вищі психічні процеси 3 характерним для них аналізом і синтезом, 3 довільністю і цілеспрямованістю організації діяльності. 


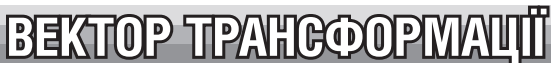

Як зазначає Л. Григор'єва [5], у дітей із порушеннями зору формування і розпізнавання образів утруднюється обмеженою інформацією, що відповідно потребує певного рівня розвитку інших когнітивних процесів. Цей рівень потребує когнітивні операції, що забезпечують пошук істотних ознак, і оволодіння стратегіями розпізнавання образів.

Труднощі у навчанні усвідомлюються дітьми в основному через ставлення до них вчителя. Гостро переживаючи їх, дитина може зневіритись у власних силах і здібностях, у неї виникає невпевненість, бажання уникнути негативного емоційного напруження, пов'язаного із навчанням.

Варто зазначити, що з поширенням в Україні інклюзивного навчання особливо гостро постає необхідність психологічної готовності педагогів до взаємодії $з$ дітьми, які мають порушення роботи зорового аналізатора.

Першокласників з порушеннями зору, які через різні причини не можуть впоратись із навчальним навантаженням, часто вчитель вважає невстигаючими, що, зокрема, призводить як до виникнення у дітей неврозів, так і до страху школи [7].

Тобто, найбільшої шкоди процесові шкільної адаптації завдають самі вчителі, які намагаються виховувати школярів шляхом «об'єктивної» критики їхніх недоліків. Дитина ще не здатна об'єктивно сприймати критичні зауваження через вікові особливості їі загальної самооцінки, яка формується переважно у результаті інтеріоризації оцінок дорослих людей та результатів провідної діяльності - навчання.

Якщо школяр сприймає результати навчання як єдиний критерій власної цінності, то він набуває властивості «обмеженої ідентичності» [1]. Виникає почуття неповноцінності, що негативно впливає на актуальну ситуацію розвитку дитини та може сформувати несприятливий життєвий сценарій.

Фрустрація потреби у визнанні може викликати у молодших школярів не тільки зниження самооцінки, але й неадекватні захисні реакції. При активному типі поведінки захист обертається агресією, компенсуючи шкільну неуспішність в інших видах діяльності. При пасивній поведінці з'являються невпевненість у собі, лінь, апатія тощо.

Висока самооцінка формується у дитини тоді, коли іï шкільна успішність відповідає зовнішнім офіційним критеріям. Але обмеженість, недостатність цих критеріїв оцінки проявляється в тому, що ситуації неуспіху призводять до зниження загальної самооцінки дитини.

Варто зазначити, що самооцінка школяра у цьому віці ще не аналітична, а синтетична. Це ймовірно цілісне емоційне ставлення до себе, аніж розумова оцінка окремих своїх якостей та рис.

Інколи страх перед школою зумовлений можливими або наявними конфліктами з ровесниками або старшими дітьми, побоюванням проявів фізичної агресії з їхнього боку. Діти з порушеннями зору, які не отримали до школи необхідного досвіду спілкування з іншими дітьми, не впевнені у собі, бояться не

«ОСОБЛИВА ДИТИНА: навчання і виховання», № 3, 2019 
виправдати очікувань значущих інших, зазнають труднощів адаптації у шкільному колективі.

Особливо це може проявлятись в умовах інклюзивного навчання, коли дитина з порушеним зором стає об'єктом глузувань з боку однолітків, які не розуміють труднощів такої дитини і не співчувають їй.

Як результат, - у дитини з порушеним зором може виникнути серйозний внутрішній конфлікт у випадку непорозумінь із однолітками. Цей конфлікт також виникає внаслідок суперечностей між вимогами інших (часто дорослих) людей і можливостями дитини, що порушує їі емоційний комфорт, гальмує формування необхідних особистісних якостей.

Часто від того, як до певних поведінкових реакцій дитини з порушеним зором поставиться вчитель залежить, як до них поставиться клас. Тому, на жаль, таких дітей часто дражнять, висміюють. Напружені стосунки з однолітками невротизують емоційно вразливих дітей, підвищують їхню агресивність або замкнутість, посилюють стан психологічного неблагополуччя. У такому разі умови навчального закладу обертаються для дитини стресогенним чинником, призводять до фрустрації їі базових особистісних потреб.

Більшість причин виникнення дезадаптації пов'язана зі ставленням до дитини та їі навчання у родині. Для багатьох сучасних сімей характерною є ситуація «дитина - кумир родини», оскільки дитина в сім'ї переважно одна. Задоволення потреб дитини та їі забаганок часто стає сенсом життя усієї сім'ї. Ці тенденції ще більш характерні для сімей, де є дитина з глибокими порушеннями зору.

На думку О. Литвака [8], зоровий дефект провокує, особливо в сфері родинних стосунків, виникнення умов, що несприятливо впливають на формування рис характеру. До таких умов він відносить як надмірне піклування з боку навколишніх, так і відсутність уваги до дитини, іiі занедбаність. У результаті у сліпих та слабозорих формуються негативні моральні (егоцентризм, егоїзм), вольові (відсутність самостійності, нерішучість, упертість, негативізм), емоційні (байдужість, душевна черствість) та інтелектуальні (відсутність цікавості, почуття нового) риси характеру.

Автор цілком слушно зауважує, що особливості особистості сліпих та слабозорих лише побічно пов'язані з дефектами зору, і більшою мірою є наслідками соціальними. Тобто, у формуванні основних властивостей особистості на перший план виходять саме соціальні чинники.

Отже, з-поміж причин шкільної дезадаптації заслуговують на першочергову увагу хибні стратегії виховання в сім'ї та школі або ї принципова розбіжність, порушення системи міжособистісних стосунків дитини у школі (з учнями та педагогами). Вартозазначити також, що дитина з глибокими порушеннями зору зазвичай традиційно потрапляе до спеціальної школи-інтернату, яка ізолює iï від родини, порушує той звичний близький емоційний контакт дитини з батьками та найближчими родичами, який виник у попередні роки. 
Проте соціальна адаптація, як і соціалізація, може бути керованим процесом. Управління ним може здійснюватися не тільки через упливу соціальних інститутів на особу в процесі їі життєдіяльності, а й шляхом саморозвитку особистості. Період навчання у школі є ключовим не тільки у становленні цілісної структури особистості, а також є одним із найважливіших у формуванні можливостей адаптаціі.

У багатьох сучасних дослідженнях акцентується увага на тому, що провідним психологічним чинником соціальної адаптації особистості виступає ії адаптаційний потенціал.

Індивідуально-психологічні особливості особистості, від яких залежить ефективність адаптації, на думку різних авторів, складають в сукупності одне 3

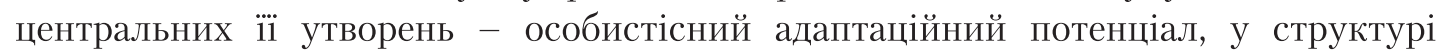
якого особистісні властивості, відповідальні за успішну адаптацію (Л. Анциферова, Д. Леонтьєв, О. Маклаков, І. Сімаєва та ін.).

Отже, під адаптивністю зазвичай розуміють наявність певних здібностей, що дають змогу особистості найбільш швидко й адекватно вирішувати проблемні ситуації та нормалізувати свою взаємодію з середовищем. Існує величезна різноманітність думок з приводу того, що саме входить у це поняття, і які властивості треба вважати адаптивними. У науковій літературі можна зустріти опис досить узагальнених особистісних якостей, таких як усвідомленість, гнучкість поведінки, здатність до внутрішніх особистісних змін, соціально-психологічна терпимість тощо. Поряд з цим, використовується просте перерахування особливостей поведінки: дружелюбність, відповідальність, відповідність поведінки етичним нормам. Якщо адаптивність розглядається як система способів, що допомагають справлятися з типовими проблемними ситуаціями, то зазначаються такі якості, як здатність приймати адекватні рішення, наявність відповідних знань та вмінь.

Аналіз публікацій, присвячених адаптаційному потенціалу особистості, показує зростаючу частоту застосування цього терміна при формулюванні, констатації адаптаційних можливостей особистості. Водночас, помітна неоднорідність досліджень, у яких виробляється операціоналізація, визначення його змісту. Під адаптаційним потенціалом зазвичай розуміється сукупність якісно своєрідних індивідуально-психологічних властивостей, набір яких неоднаковий у різних дослідженнях. Висновок про стан особистісного адаптаційного потенціалу робиться в результаті аналізу рівневих характеристик цих властивостей, об'єднаних у групу, й викликає складності зіставлення досліджень і виділення загальних властивостей, чинників і закономірностей формування адаптаційного потенціалу. Спостерігається суперечність між пояснювальною цінністю цього поняття і неоднозначністю його визначення.

Відповідно до наших теоретичних позицій, ми представили адаптаційний потенціал у вигляді двокомпонентної моделі, структура якої певним чином співвідноситься із визначеною нами структурою особистісного благополуччя [2], а саме охоплює рефлексивний та ресурсний компоненти (puc. 2).

«ОСОБЛИВА ДИТИНА: навчання і виховання», № 3, 2019 


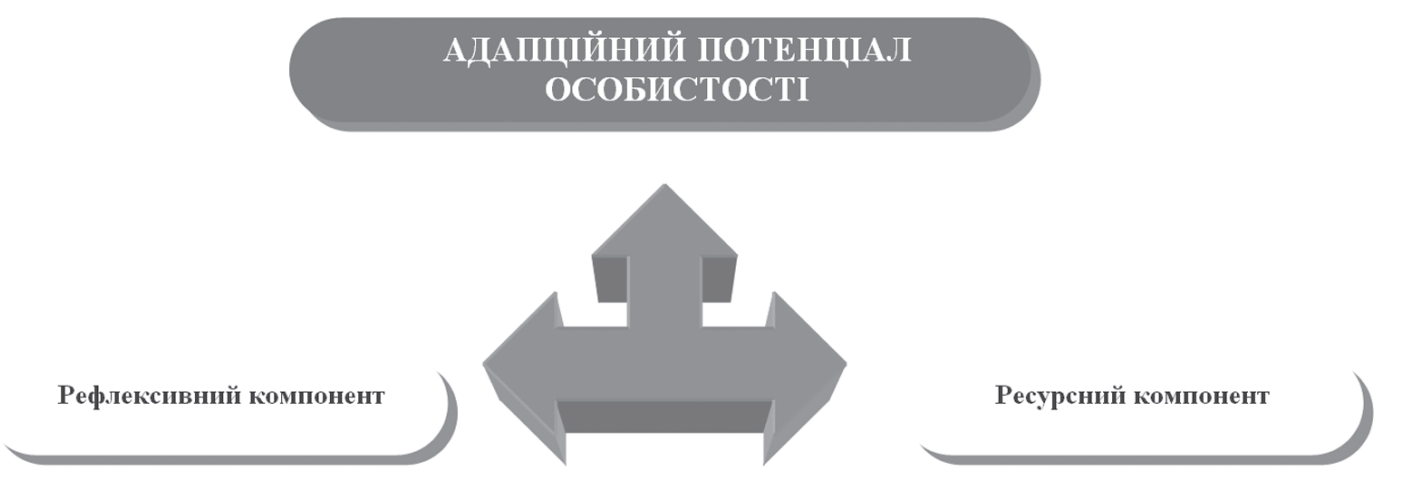

Рuc. 2. Бінарна модель адаптаційного потенціалу особистості

На нашу думку, рефлексивний компонент забезпечує загальну готовність особистості до адаптації, як до умов кожної конкретної ситуації, так і загалом, до умов соціального мікросередовища, тоді, як ресурсний компонент забезпечує для цього певний необхідний інструментарій, який визначає як і яким чином буде відбуватися процес соціальної адаптації. Розглянемо іх більш детально.

3-поміж складників, які входять до структури обох компонентів адаптаційного потенціалу, ми умовно виділили дві основні групи: інтрасуб'єктні та інтерсуб'єктні складники [7]. Оскільки їня роль і значення в розвитку адаптаційного потенціалу не однакова, проаналізуємо їх.

Як ми зазначали вище, уявлення про себе певним чином впливає на здатність особистості до повноцінного функціонування, можливість успішної соціальної адаптації та інтеграції в соціум. Ставлення до себе та інших, ставлення до умов життя мають важливе для особистості значення з погляду засвоєних нормативних уявлень про «сприятливе» зовнішнє середовище.

Стійкість і якість ставлень до себе та до інших визначають можливість автономності й соціальної компетентності особистості. Позитивні відносини сприяють усвідомленню мети й сенсу існування, що $є$ умовою самоактуалізації й прагнення до особистісного росту. Високі показники в рамках цього компонента означають сформоване позитивне ставлення до себе й свого минулого, усвідомлення й прийняття різних сторін свого «Я», наявність здатності одержувати задоволення від теплих, довірливих стосунків з іншими й піклуватися про благополуччя інших, здатність до емпатіі.

Як зазначалось нами раніше, благополуччя особистості пов'язане з реалізацією потреб, що мають соціальний контекст (потреба в автономії й компетентності), самореалізації [2].

Крім того, на нашу думку, рефлективний компонент адаптаційного потенціалу має в своїй структурі певні соціально-нормативні ціннісні установки, реалізація яких визначена усією сукупністю умов соціалізації та соціальної адаптації, як у суб'єктивному, так і в об'єктивному планах. 


\section{BEKSOP TPAHROCOPMANUIII}

Як зазначає М. Тіткова [10], рефлексивна активність - це багатокомпонентне структурне психологічне утворення, що розкриває взаємозв'язок власного «Я» особистості й зовнішньої реальності $з$ метою актуалізації адаптаційного потенціалу. Рефлексивна активність, як властивість особистості, що розвивається, проявляється в готовності до взаємодії із власним «Я», фокусуванні свідомості на власному «Я», актуалізації процесу самоаналізу в особистісно значущих життєвих ситуаціях, широті діапазону й когнітивної складності самоописів, емоційного залучення в процес взаємодії із власним «Я», трансформацію життєвих цінностей і цінності власного «Я». Рефлексивна активність проявляється в єдності й взаємозумовленості когнітивного та емоційного компонентів особистості.

Розвиток рефлексивної активності сприяє підвищенню адаптаційного потенціалу, що проявляється в підвищенні самоцінності й пошуку в собі позитивного, зниження тривожності.

Переходячи до розгляду ресурсного компоненту, хочемо нагадати, що він, на нашу думку, спирається на збереження психічних процесів і функцій, або їхню компенсацію, позаяк зоровий дефект часто викликає функціональні обмеження.

Ресурсний компонент, з нашої точки зору, характеризується соціальним досвідом (способами подолання депривації або фрустрації, комплексом паттернів поведінки (поведінковий репертуар), соціальною орієнтацією, соціальним статусом тощо).

Ресурси - це способи й засоби здійснення діяльності. Ресурси людини як суб'єкта діяльності - це біофізичні, психофізіологічні й особистісні ресурси, компетенції й компетентності.

3 позицій ресурсного підходу, потенціал людини можна розглядати як систему поновлюваних, частково поновлюваних і непоновлюваних ресурсів, які проявляються або можуть проявлятися в реальній діяльності. При цьому людський потенціал корисніше розглядати не як певний обсяг ресурсів, які людина може задіяти протягом свого життя і які дані ій від народження, а як щоденну, щохвилинну здатність до виробництва таких ресурсів. Потенціал - кластер ресурсів, певний рівень розвитку яких забезпечує можливість успішного виконання певного кола або класу завдань.

Висновки. Підбиваючи підсумок теоретичного огляду питання, необхідно відзначити, що, незважаючи на велику кількість досліджень у галузі соціальної адаптації, взаємозв'язок психологічних характеристик та адаптаційного потенціалу особистості на сьогодні недостатньо вивчена.

Проведений аналіз дефініцій даного феномена дає підстави виділити деякі його загальні, основні риси й показати, що, зазвичай, особистісний адаптаційний потенціал:

1) розглядають як інтегральну змінну, що характеризує сукупність індивідуально-психологічних ознак, що обумовлюють ефективність адаптації;

«ОСОБЛИВА ДИТИНА: навчання і виховання», № 3, 2019 73 
2) має властивості складної системи й, відповідно, системний аналіз виступає основним підходом до його дослідження;

3) охоплює не тільки наявні прояви адаптаційних здатностей, а й латентні властивості, які можуть виявитися у зміні змісту, сили й напрямів впливу адаптогенних чинників;

4) визначає межі адаптаційних можливостей особистості й стійкості до чинників, що впливають на неї, містить передумови до певного діапазону відповідних адаптаційних реакцій;

5) пов'язаний 3 віковими та психологічними особливостями, при цьому активність особистості виступає як важлива й необхідна умова, що регулює міру реалізації потенційних можливостей.

Поширення поняття адаптаційного потенціалу особистості в практиці психолого-педагогічного супроводу обумовлено завданнями оцінки адаптаційних можливостей дитини 3 порушеним зором, диференціації стійких порушень адаптації і скороминущих дезадаптивних станів, а також з'ясування психологічного змісту психосоматичних захворювань [7].

Уявлення про природу порушень адаптації, кордони й властивості адаптаційного потенціалу дослідники визначають як важливі передумови ефективності корекційно-реабілітаційних заходів.

Отже, адаптаційний потенціал прийнято розглядати як системну властивість особистості, що обумовлює границі їі адаптаційних можливостей та характер протікання адаптації особистості у відповідь на вплив тих або інших чинників і умов середовища. Особливості адаптаційного потенціалу, опосередковуючи вплив чинників середовища, визначають напрям, зміст, інтенсивність адаптаційної відповіді особистості.

Аналіз структури адаптаційного потенціалу, ієрархії його елементів, якісної своєрідності його внутрішніх і зовнішніх зв'язків, можливо, є ключем до коректного й надійного прогнозування адаптаційного процесу, підвищення ефективності програм його психолого-педагогічного супроводу, наданню індивідуалізованої психологічної допомоги.

\section{ЛITEPATУPA}

1. Erikson E. H. Identity and the Life Cycle / E. H. Erickson. - New York : Int. Univ. Press, 1959. - P. 45-55.

2. Kobylchenko Vadym. Personal well-being as theoretical construct / Vadym Kobylchenko // TEKA-Archives of the Commission of Medical Sciences, Polish Academy of Sciences Branch in Lublin. - Lublin: Towarzystwo Wydawnictw Naukowych LIBROPOLIS, 2014. - Vol. 2. - № 1. P. 9-13.

3. Александровская Э. М. Психологическое сопровождение школьников. Учебное пособие для вузов. / Э. М. Александровская, Н. И. Кокуркина, Н. В. Куренкова - М.: Академия, 2002. - 208 с.

4. Венгер А. Л. Психологическое консультирование и диагностика. Часть 1. / А. Л. Венгер. - М.: Генезис. 2001. -128 с. 
5. Григорьева Л. П. Формирование высших форм зрительного восприятия как основа компенсации нарушений когнитивного развития детей / Л. П. Григорьева // Дефектология. 2000. - № 1. - C. 3-15.

6. Дорожевещ Т. В. Психологическая помощь детям: арт-техникики активизации внутренних ресурсов ребенка // Практична психологія та соціальна робота / Т. В. Дорожевец. 1998. - № 6-7. - С. $37-42$.

7. Кобильченко В. В. Теоретичні основи психолого-педагогічного супроводу молодших школярів з порушеннями зору / В. В. Кобильченко. - Полтава: ТОВ «Фірма «Техсервіс», 2017. $-367 \mathrm{c}$.

8. Литвак А. Г. Тифлопсихология / А. Г. Литвак.- М. : Просвещение, 1985. - 208 с.

9. Солнцева Л. И. Современная тифлопедагогика и тифлопсихология в системе образования детей с нарушениями зрения. - М. : Полиграф-Сервис, 1999. - 180 с.

10. Титкова М. С. Рефлексивная активность в структуре адаптационного потенциала личности : автореф. ... канд. дис. психол. наук. / М. С. Титкова. - СПб., 2007.

\section{REFERENCES (TRANSLATED AND TRANSLITERATED)}

1. Aleksandrozskaja, Je. M. (2002). Psihologicheskoe soprovozhdenie shkol'nikov. Uchebnoe posobie dlja vuzov. M.: Akademija. [In Russian].

2. Dorozhevec, T. V. (1998). Psihologicheskaja pomoshh' detjam: art-tehnikiki aktivizacii vnutrennih resursov rebenka. Praktichna psihologija ta social'na. 6-7. [In Russian].

3. Grigor'eva, L. P. (2000). Formirovanie vysshih form zritel'nogo vosprijatija kak osnova kompensacii narushenij kognitivnogo razvitija detej. Defektologija. 1. [In Russian].

4. Kobylchenko, V. V. (2017). Teoretychni osnovy psykholoho-pedahohichnoho suprovodu molodshykh shkoliariv z porushenniamy zoru. Poltava: TOV «Firma «Tekhservis». [In Ukrainian].

5. Litvak, A. G. (1985). Tiflopsihologija. M. : Prosveshhenie. [In Russian].

6. Solnceva, L. I. (1999). Sovremennaja tiflopedagogika i tiflopsihologija v sisteme obrazovanija detej s narushenijami zrenija. M. : Poligraf-Servis. [In Russian].

7. Titkova, M. S. (2007). Refleksivnaja aktivnost' v strukture adaptacionnogo potenciala lichnosti : avtoref. ... kand. dis. psihol. nauk. - SPb. [In Russian].

8. Venger, A. L. (2001). Psihologicheskoe konsul'tirovanie i diagnostika Chast' 1. M.: Genezis. [In Russian]. 